
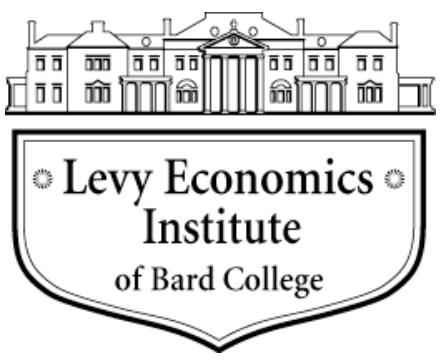

Working Paper No. 765

\title{
The Economic Crisis of 2008 and the Added Worker Effect in Transition Countries
}

by

\author{
Tamar Khitarishvili* \\ Levy Economics Institute of Bard College
}

May 2013

*The author thanks Rania Antonopoulos and the participants of the Economics Seminar at the Levy Economics Institute for helpful comments. Any remaining errors are my own.

The Levy Economics Institute Working Paper Collection presents research in progress by Levy Institute scholars and conference participants. The purpose of the series is to disseminate ideas to and elicit comments from academics and professionals.

Levy Economics Institute of Bard College, founded in 1986, is a nonprofit, nonpartisan, independently funded research organization devoted to public service. Through scholarship and economic research it generates viable, effective public policy responses to important economic problems that profoundly affect the quality of life in the United States and abroad.

Levy Economics Institute

P.O. Box 5000

Annandale-on-Hudson, NY 12504-5000

http://www.levyinstitute.org

Copyright (C) Levy Economics Institute 2013 All rights reserved

ISSN 1547-366X 


\begin{abstract}
Following the financial crisis of 2008, transition countries experienced an increase in female labor force participation rates and a decrease in male labor force participation rates, in part because male-dominated sectors were hit the hardest. These developments have prompted many to argue that women have been spared the full-blown effects of the crisis. In this paper, we critically evaluate this claim by investigating the extent to which the increase in the female labor force participation rate may have reflected a distress labor supply response to the crisis. We use the data on the 28 countries of the transition region assessed in the 2010 Life in Transition Survey. We find the presence of the female added worker effect, driven by married 45- to 54year-old women with no children in the household. This effect is the strongest among the region's middle-income countries. Among men, a negative relationship between labor force participation and household-specific income shocks is indicated. Unlike the differences in the response to household-specific income shocks, the labor supply response to a weaker macroeconomic environment is negative for both men and women-hinting at the presence of the "discouraged worker" effect, which cuts across gender lines. We conclude that the decrease in men's labor force participation observed during this crisis is likely a combined result of the initial sectoral contraction and the subsequent impact of the discouraged worker effect. For women, on the other hand, the added worker effect appears to outweigh the discouraged worker effect, contributing to an increase in their labor force participation rate. Our findings highlight the presence of heterogeneity in the way in which household-specific shocks, as opposed to economy-wide conditions, affect both female and male labor force participation rates.
\end{abstract}

Keywords: Gender Economics; Economic Crisis; Added Worker Effect; Labor Supply Response; Labor Force Participation; Central and Eastern Europe; Former Soviet Union; Transition Countries

JEL Classifications: J16, J21, P20 


\section{INTRODUCTION}

The recent financial crisis pushed the economies of Central and Eastern Europe and former Soviet Union (CEE/FSU) into a sudden recession, the worst region-wide experience since the "transitional recession" of the early 1990s. ${ }^{1}$ The contraction in the economic activity was to a large extent an outcome of the export-led growth strategy and to a lesser degree an outcome of the dependence on foreign capital. These factors fueled the brisk regional output growth during this decade prior to 2008, which averaged 6.44 percent. These same factors, however, left the region highly susceptible to negative external shocks. The crisis resulted in the regional output shrinking by 4.8 percent in 2009 , excluding energy-exporting transition countries. ${ }^{2}$ In comparison, the United States' economy shrank by 3.1 percent, whereas the European Union's economy shrank by 4.3 percent.

Despite this output contraction, the countries of the region were able to avert a full-scale financial collapse because of an overall sound financial system and strong fiscal positions. The subsequent domestic and international policy response contributed to the rebound in the region's macroeconomic indicators, with GDP growth reaching 4.6 percent in 2010. However, the prolonged eurozone sovereign debt crisis stalled the recovery, slowing down the output growth to just above 3 percent, according to the most recent forecasts by the European Bank for Reconstruction and Development (EBRD) and by the United Nations (UN) (EBRD 2013; UN 2013).

Underlying the vulnerability of the recovery are weak labor markets. According to the most recent estimates, the regional unemployment rate reached 14.19 percent, the highest rate in a decade (EBRD 2013). Past experience has demonstrated that the labor market impact of crises may differ by gender (Rubery 1988). During this crisis, men's unemployment rate in the transition region increased more sharply than women's. Furthermore, the decline in their employment rate was more pronounced than the corresponding drop for women. Finally, men's labor force participation rate declined, whereas women increased their involvement in the labor force. These developments prompted many to argue that, unlike previous crises, which

\footnotetext{
${ }^{1}$ There are 29 countries in the region: Albania, Armenia, Azerbaijan, Belarus, Bosnia and Herzegovina, Bulgaria, Croatia, Czech Republic, Estonia, Georgia, Hungary, Kazakhstan, Kosovo, Kyrgyz Republic, Latvia, Lithuania, Macedonia, FYR, Moldova, Montenegro, Poland, Romania, Russian Federation, Serbia, Slovakia, Slovenia, Turkmenistan, Ukraine, and Uzbekistan.

${ }^{2}$ The energy-exporting countries include Azerbaijan, Kazakhstan, Russian Federation, and Turkmenistan. Their inclusion diminishes the magnitude of the contraction to a still sizable 3.84 percent.
} 
disproportionately hurt the female labor force, this crisis has been particularly devastating to men (Cho and Newhouse 2013).

In this paper, we critically evaluate this claim by assessing the extent to which the increase in the female labor force participation rate, in particular, may reflect a distress response to the crisis, as has been found to be the case during past crises in other regions (Cerrutti 2000; Sabarwal, Sinha, and Buvinic 2011). We do so by investigating the presence of the added worker effect, broadly defined as an increase in labor supply in response to an income shock.

The analysis of the forces behind the gender differences in the movements of labor force participation rates is particularly salient for transition countries. This is the case in part because of their shared socialist legacy of gender equality and in part because of the post-socialist deterioration of the gender balance in the region. The regional evidence from past crises reveals that labor supply responses were commonly used to mitigate the impact of crises (Lokshin and Yemtsov 2004). The evidence from this crisis is limited and reveals no labor supply response to the crisis or very weak added worker effect among women (Cho and Newhouse 2013; Bhalotra and Umaña-Aponte 2010). However, these findings are either limited to middle and high-middle income transition countries or are based on employment outcomes. In this paper, we address these limitations by including the data for 28 countries of the region and considering labor force participation outcomes.

The rest of the paper is structured as follows. The next section presents some of the key features of the crisis in the transition region and establishes crisis-related gender dynamics in their labor markets. The subsequent sections discuss the methodology and provide data summary. Empirical results and robustness checks follow. We conclude the paper with a discussion of the results and their implications.

\section{BACKGROUND}

The transition region includes a heterogeneous group of countries. Before the crisis in 2007, their per capita GDP ranged from $\$ 217$ in Tajikistan to $\$ 13,378$ in Slovenia. ${ }^{3}$ Although the crisis, which began in the summer of 2007 in the US mortgage sector, quickly spilled over to the Western European financial markets, it didn't hit the region until late 2008 and early 2009. Its initial financial impact was, in fact, surprisingly mild. In 2008, transition countries maintained a

\footnotetext{
${ }^{3}$ The numbers are expressed in constant 2000 US dollars.
} 
moderate 5.83 percent average growth rate and the unemployment rate declined to 11.93 percent in 2008 from 12.49 percent in 2007. This was despite their relatively high exposure to international financial and output markets as evidenced by the higher than 40 percent share of exports in the GDP throughout the last decade. Indeed, financial capital continued to flow in during the first half of 2008 and, even when the signs of financial contagion became visible by the last quarter of 2008, capital inflows remained positive.

It was through the real side of the economy that the full-blown wave of the crisis finally hit the region in the last quarter of 2008 with a drop in exports reaching as high as 17 percent in Moldova. The slide continued in 2009 as exports shrank further in the majority of countries, with Ukraine experiencing a 22 percent drop. The subsequent contraction in output was almost universal: with the exception of Poland, all countries of the region experienced negative output growth in at least one quarter. On an annual basis, all but nine countries of the region observed a drop in the GDP in 2009. Out of the nine that didn't contract, three were energy-exporting Kazakhstan, Turkmenistan, and Azerbaijan. Agriculture was the only sector that grew in 2009, at about 1 percent. The slowdown of industry and services, which started already in 2008, turned into negative digits by 2009 , with industry shrinking the most at 7.84 percent and services at 1.45 percent.

The magnitude of the recession that each country experienced was tied to the initial output composition, the degree of export dependence, and the performance of the main trading partners, with open economies contracting more than closed economies. The recession was exacerbated by the eventual decline in the foreign direct investment (FDI) that followed the export contraction, domestic credit contraction, and a drop in remittances (EBRD 2009).

By 2010, the region appeared to have bounced back, with output growth turning positive in all but three countries. By 2011, the GDP growth rate reached 4.6 percent (EBRD 2013). From today's vantage point, it can be argued that the buffers that prevented the crisis from entering the region with full force until 2009 and allowed it to start growing again only a year later were the overall strong fiscal positions, the relatively healthy financial sector, and the FDIdominated financial flows, less prone to the sudden reversals that characterized the Asian financial crisis (EBRD 2009). A further contributing role was likely played by active international and domestic policy responses. The adopted domestic policy tools have differed, but overall the fiscal response was expansionary, with per capita government expenditures increasing from $\$ 623$ in 2007 to $\$ 650$ in 2010. 
However, the robust turnaround has proven to be short-lived mainly due to the protracted nature of the eurozone sovereign debt crisis, which stalled the recovery of exports and domestic credit and dented the region's growth prospects. By 2012, the GDP growth rate had slowed down to 2.6 percent and in 2013 is forecasted to rise to between 3.1 percent and 3.6 percent (EBRD 2013; UN 2013).

The vulnerability of the economic recovery in the region has been amplified by the weak state of the labor markets. Despite the turn-around in output in 2010, the unemployment rate continued to grow, reaching 14.19 percent, according to the most recent regional update (EBRD 2013). The youth unemployment rate, largely on the decline during the previous decade, spiked up from 19.96 percent in 2008, the lowest rate in the previous ten years, to 22.42 percent in 2009 and to 26.00 percent in 2010 (International Labour Organization 2012).

Crises-induced labor market outcomes have historically differed by gender. The socialist collapse resulted in a worsening of labor market conditions, evidenced by a spike in the unemployment rate and a decline in employment and labor force participation rates of both men and women. However, in its initial aftermath, women's position in the labor markets weakened more compared to men's, as their employment rate dropped more sharply. Women also withdrew from the labor force in proportionately greater numbers.

During this crisis, on the other hand, the worsening of the labor market indicators was accompanied by a very different gender picture. Both unemployment rates increased; however, in 2010 men's unemployment rate surpassed that of women for the first time since 2000. Moreover, although both employment rates decreased, women's employment rate contracted proportionately less, indicating that employment losses were more substantial among men than among women. Importantly, between 2008 and 2010, men's labor force participation rate slightly decreased from 73.89 percent to 73.71 percent; however, women's labor force participation rate slightly increased from 59.43 percent to 60.01 percent.

The literature has developed a conceptual framework for analyzing these patterns and has proposed a number of channels potentially responsible for the heterogeneous impact of crises on men and women's labor force participation rates (Rubery 1988). Broadly defined, these include gender differences in the occupational and sectoral distribution and genderdependent labor demand and labor supply responses. Occupational and sectoral segregation by gender has been shown to be a frequent conduit of the first-round effects of crises. Women worldwide are more likely to work in the service sector, whereas men are more likely to work in 
manufacturing (ILO 2010). During past crises, women working in export-oriented manufacturing sectors suffered disproportionately high losses (Antonopoulos 2009). However, because this crisis hit the male-dominated construction and manufacturing sector the hardest, men likely experienced greater job losses than women and possibly exhibited more active withdrawal from the labor force.

From the labor demand side, the second-round adjustments that firms make in response to crises, too, can translate into different labor market outcomes for men and women. For example, firms' perceptions regarding the productivity and attachment of workers are often an influential determinant of hiring and firing decisions. If women are viewed to be less attached to the labor market due to their reproductive role and cultural expectations of their household responsibilities, they will be more likely to be let go. In fact, some studies (Singh and Zammit 2000) argue that these perceptions explain why women suffered disproportionately higher job losses during the Asian financial crisis. This explanation can be viewed under the umbrella of the buffer hypothesis, according to which women are a flexible labor reserve that enters the workforce during expansions and exits it during economic downturns in greater proportions than men, resulting in a pro-cyclical movement of the female employment rates (Rubery 1988). On the other hand, because women tend to receive lower pay, hiring women over men can be viewed as a cost-saving strategy by the crisis-hit firms, resulting in an increase in women's wage employment during crises at the expense of men. This possibility is known as the substitution hypothesis and results in a counter-cyclical behavior of the female employment rates (Rubery 1988). Using a sample of 17 middle-income countries, Cho and Newhouse (2012) find some evidence in support of this hypothesis during the most recent crisis. Whereas these hypotheses are directly applicable only to employment outcomes, they may also apply to shifts in the labor force participation rates.

\section{CRISES AND LABOR SUPPLY RESPONSES: LITERATURE REVIEW}

Our interest in this paper lies in understanding the third mechanism linking crises and labor market outcomes of men and women - that of households' labor supply responses to income shocks induced by crises. Similar to the demand-side responses, this mechanism, too, can be viewed as a second-round impact of a crisis (Heltberg et al. 2012; Sabarwal, Sinha, and Buvinic 2011). 
Labor supply changes can take place in response to both household-specific income shocks and economy-wide shifts. Some examples of household-specific income shocks are employment loss, wage reductions, or a decrease in remittances. We study a particular type of a household-specific income shock, stemming from the loss of another household member's job. This shock can induce an increase or a decrease in the desired labor supply. The positive labor supply response of one household member in response to the loss of another household member's job is known in the literature as the added worker effect. ${ }^{4}$ The added worker effect can be induced via at least two channels. First of all, the increase in labor supply can be a coping strategy aimed at compensating for the income reduction due to a household member's job loss, the channel known as the income effect (McKenzie 2003). At the same time, it can result from the reduction in the reservation wage of the formerly inactive household members and their entry into the labor force, now that the newly unemployed individuals can take over some of their household responsibilities. On both counts, women are the more likely drivers in the added worker effect. On the first count, they are the ones more likely to be outside of the labor force to begin with and hence available to respond by joining the labor force. On the second count, given that women are the primary providers of household needs, such as care for children, adults, and the elderly, daily maintenance, cooking, shopping, etc., the reservation wages are likely to be more sensitive to others taking over some of their household responsibilities.

The loss of another household member's job can also cause a negative labor supply response. The income reduction due to the loss of a household member's job may induce a withdrawal from the labor force if households are forced to substitute market goods for household-produced goods. In such a case, some previously unemployed individuals may stop looking for paid work opportunities and exit the labor force altogether. Arguably, the unemployed women are the more likely candidates to do so due to their role as primary producers of household goods.

Beyond the household-specific shocks, economy-wide shocks, too, can induce changes in the labor supply even if households have not been directly affected by a household-specific shock. Some studies have, in fact, interpreted the evidence of an increase in labor supply in

\footnotetext{
${ }^{4}$ This definition is an extension of the original definition of the added worker effect, which entails the increase in wives' labor force participation in response to the spousal loss of a job (e.g., Lundberg 1985). More recent work studies the responses of household members as opposed to wives only (Cerrutti 2000), and considers the change in the working hours of those experiencing the initial shock and of those responding to it as opposed to employment loss and entry from inactivity into labor force (Gong 2011).
} 
response to weaker macroeconomic conditions as a manifestation of the added worker effect (Congregado, Golpe, and van Stel 2011; Cunningham 2001). On the other hand, the crisisinduced reduction in overall wages may lower the labor force participation rate by reducing the opportunity cost of leisure, resulting in an increase in leisure and a drop in the labor supply (McKenzie 2003). For many individuals, this reduction may also pull the prevalent wage offers below their reservation wages, inducing them to exit the labor force. Finally, the lower odds of finding a job in a weak economic environment may raise perceived and actual job search costs, resulting in the discouraged worker effect. It is noteworthy that, although the literature has commonly contrasted the added worker effect and the discouraged worker effect (Congregado, Golpe, and van Stel 2011), the first is properly defined as a response to household-specific income shocks and the second as a response to the worsening of the macroeconomic environment.

Historical evidence of the added worker effect from developed countries is mixed, although recent literature argues against the presence of a considerable added worker effect. This, at least in part, has been attributed to the presence of strong unemployment-insurance and financial systems in developed countries (e.g., Juhn and Potter 2007; Stephens 2002; PrietoRodriguez and Rodriguez-Gutierrez 2003).

Even in developing countries, however, despite weaker unemployment insurance mechanisms and higher barriers to accessing credit, the available evidence reveals a complex story and a range of experiences. Fernandes and de Felicio (2005) find that the added worker effect among wives in Brazil is between 7.35 percent and 12 percent, attributing it to the absence of the unemployment insurance mechanisms. McKenzie (2004) reports the added worker effect of 11 percent in Argentina. Focusing on the case of Mexico before the 1994 Peso crisis, Cunningham (2001) finds the presence of the added worker effect among wives in response to the husband's loss of a job as well as in response to higher unemployment rates. During the Peso crisis, evidence once again indicates the presence of the added worker effect among wives with respect to the spousal job loss (Skoufias and Parker 2006). However, unlike the pre-crisis period, there is no evidence of the added worker effect in response to the worsening macroeconomic environment (McKenzie 2003). Evidence from Turkey reveals the presence of the added worker effect among wives in response to husband's loss of a job during the 1994 economic crisis (Başlevent and Onaran 2003) and during the last decade (İlkkaracan and Değirmenci 2013, forthcoming; Karaoglan and Okten 2012). In response to unemployment 
rates, on the other hand, Karaoglan and Okten (2012) find support for the discouraged worker effect. These findings underscore the heterogeneity in which households respond to idiosyncratic shocks as opposed to macroeconomic shocks.

The studies with weaker or complete lack of evidence of the added worker effect in developing countries provide a fruitful ground for investigating a range of coping strategies and the interplay among them. Posadas and Sinha (2010) report the added worker effect of 2.1-5.1 percent among wives in Indonesia, attributing the relatively low magnitude to the fact that the main transmission mechanism of the crisis in Indonesia was the change in the wages, rather than the loss of employment. Serneels (2002) finds no evidence of the added worker effect among women in response to other household member's loss of a job in Ethiopia, and points to the use of other strategies, such as tapping into savings to compensate for the loss of income. Similarly, McLaren (2012) finds no evidence of the added worker effect among men or women in response to another household member's loss of a job in South Africa, concluding that households depend on remittances as the buffer for the loss of employment income. In the case of South Africa, especially, extremely high unemployment rates largely preclude the use of labor supply as a coping strategy and indeed result in the dominance of the discouraged worker effect. ${ }^{5}$ The findings of no added worker effect in Serneels (2002) and McLaren (2012) may be, in part, due to the use of another household member's job loss (rather than a spousal job loss). For example, Cunningham (2001) finds no evidence of the added worker effect with respect to another household member's job in Mexico. But her evidence with respect to the spousal job is conclusive in favor of the added worker effect. Nevertheless, the link connecting these studies is the emphasis that they place on the importance of other coping strategies.

Considering transition countries, literature has evaluated the gender impact of crises in general terms (Unal, Dokmanovic, and Abazov 2010; UN 2009). However, more work needs to be done to develop a better understanding of the gender patterns in the labor supply responses to crises in the region. This is the case, in part, due to the unavailability or poor quality of the data from the early transition period. Lokshin and Yemtsov (2004) evaluate different coping strategies used by households in Russia after the 1998 financial crisis and find that labor supply responses were used as an important strategy. However, they stop short of estimating the labor

\footnotetext{
${ }^{5}$ In a related finding, the evidence from Spain reveals the presence of a threshold unemployment rate beyond which the discouraged worker effect dominates the added worker effect (their estimate of the threshold for Spain for the recent crisis is 11.7 percent) (Congregado, Golpe, and van Stel 2011).
} 
supply changes in response to household-specific shocks and do not provide a gender picture. The evidence from the recent crisis is limited, but appears to lean against the presence of the added worker effect (Cho and Newhouse 2012; Bhalotra and Umaña-Aponte 2010). Cho and Newhouse (2012) use data from six middle- to higher-middle income transition countries to reach their conclusion of the weak added worker effect. However, because these countries also have stronger social safety nets and financial systems, the results might not be generalizable to the region as a whole. ${ }^{6}$ Bhalotra and Umaña-Aponte (2010) do incorporate mostly lower-income transition countries and find no evidence of the added worker effect; however, their conclusions are based on the lack of a relationship between the employment status and per capita GDP, rather than between the labor force status and household-specific shocks. The latter relationship represents a more appropriate measure of the added worker effect because it reflects the desire to work, ${ }^{7}$ whereas employment outcomes are a result of joint labor supply and labor demand decisions. This study attempts to address these limitations by evaluating a sample of 28 transition countries and considering the relationship between labor force status and householdspecific shocks in order to assess the presence of the added worker effect.

\section{METHODOLOGY AND DATA}

The individual and household variables in our dataset are based on the 2010 Life in Transition Survey, conducted by the EBRD at the end of 2010 (EBRD 2012). The survey includes questions covering demographic and socioeconomic characteristics as well as perceptions and attitudes about political, economic, and social issues. The survey covers all 29 countries of the transition region and includes the economic crisis module, which asks questions regarding the ways in which the recent crisis has affected the households. ${ }^{8}$ The survey contains data on 32,084 households from the transition region, a little over 1,000 per country for each of the 28 countries

\footnotetext{
${ }^{6}$ Estimating our model using their sample of transition countries, we also find no evidence of the added worker effect. Cho and Newhouse (2012) use Bulgaria, Latvia, Lithuania, Macedonia, Poland, and Romania.

${ }^{7}$ To match the approach of Bhalotra and Umaña-Aponte (2010), we re-estimate our model using employment status (instead of the labor force participation status) as the dependent variable and per capita GDP as the economywide shock variable (in addition to the household-specific loss of another household member's job). Similar to these authors, our findings reveal no evidence of the added worker effect into employment with respect to per capita GDP. Bhalotra and Umaña-Aponte (2010) use Albania, Azerbaijan, Armenia, Kazakhstan, Kyrgyzstan, Moldova, Turkmenistan, Uzbekistan, and Ukraine in their estimation.

${ }^{8}$ We drop the observations for Turkmenistan, for which variables for only 27 households are available. Therefore, our estimation includes data from 28 countries of the transition region. In addition to the transition region, the dataset includes data for France, Germany, Italy, Mongolia, Sweden, the UK, and Turkey, which are not used in this study.
} 
used in the analysis. The survey followed a two-stage clustered stratified sampling design. In the first stage, local electoral territorial units were used as Primary Sampling Units (PSUs) and, in the case of most countries, 50 PSUs were selected with the likelihood of selection being proportional to the PSU size. In the second stage, households were selected within each PSU with the goal of ensuring that each household in a given country had an equal probability of being selected. As such, the survey sample was designed to be representative at the country level.

We narrow down the sample to the individuals 18-64 years old, exclude individuals out of the labor force who reported being retired or students, as well as observations with missing values, resulting in 22,067 observations. The construction of the variable representing the household-specific shock places additional constraints on the data. The question of interest is posed as "has head of household lost job" or "has other household member lost job" in the last two years. Hence, with the exception of the household head, the survey does not identify specifically which household members have lost a job. In order to identify with certainty that another household member has lost a job, we first look at the non-household-head respondents and identify if the head has lost a job. Next, for household-head respondents, we identify if another household member has lost a job. We drop the observations for which the householdhead respondents respond that they were the only ones in the household who have lost a job. In addition, we drop the observations for which non-household-head members state that only nonhousehold-head members have lost a job, since we cannot identify with certainty that it was not the respondents themselves that have lost the job. These constraints bring the sample further down to 18,234 households.

Our choice of the loss of another household member's job rather than a spousal job loss as the preferred specification is determined by the extended household structure in the region and, more generally in developing countries (see, also, Bhalotra and Umaña-Aponte 2010; Serneels 2002). Indeed, 41.69 percent of the households in our sample have three or more adults, as compared to only 19.40 percent of the households in the US, which were shared households in $2010 .^{9}$ In order to place our results in the context of the studies that evaluate the added worker

\footnotetext{
${ }^{9}$ Shared households are defined as households that contain an "additional adult" (a resident 18 and older who is neither the householder, the householder's spouse, nor the householder's cohabiting partner) (US Census Bureau 2012).
} 
effect with respect to the spousal job loss, we report the results with respect to the spousal loss of a job, as well.

In assessing the presence of the labor supply response to an income shock, we use the labor force participation status as our dependent variable (see, also, Prieto-Rodriguez and Rodriguez-Gutierrez 2003; Baslevent and Onaran 2003). The dependent variable was constructed by first identifying individuals who were employed for pay at the time of the survey. Next, out of the individuals who did not have a job, we identified those who were looking for a job and classified them as unemployed. The employed and unemployed then together comprised the labor force. The individuals who held no jobs and were not looking for one were classified as out of the labor force.

In our estimation, the dependent variable $y_{i}$ takes the value 1 if individual $i$ is active in the labor force and 0 if individual $i$ is inactive. We estimate a binomial logit model, in which $y_{i}$, conditional on the vector of regressors $X_{i}$, follows the logistic distribution:

$$
\operatorname{Pr}\left(y_{i}=1 \mid X_{i}\right)=\frac{\exp \left(X_{i}^{\prime} \beta\right)}{1+\exp \left(X_{i}^{\prime} \beta\right)}=\Lambda\left(X_{i}^{\prime} \beta\right) .
$$

In this specification, the marginal effect with respect to continuous variables for individual $i$ can be defined as:

$$
M E_{i}=\frac{\partial \Lambda\left(X_{i}^{\prime} \beta\right)}{\partial X_{i}}=\Lambda\left(X_{i}^{\prime} \beta\right)\left(1-\Lambda\left(X_{i}^{\prime} \beta\right) \beta .\right.
$$

The marginal effects with respect to a binary variable $d$ for individual $i$ can be defined as:

$$
M E_{i}=\operatorname{Pr}\left(y_{i}=1 \mid \bar{X}_{i \backslash d}, d=1\right)-\operatorname{Pr}\left(y_{i}=1 \mid \bar{X}_{i \backslash d,}, d=0\right),
$$

where $\bar{X}_{i \backslash d}$ is the mean of the variables in the sample, excluding $d$.

We report the marginal effects as the average of the individual marginal effects (Greene 2003, 668). Note, however, that individual marginal effects with respect to a binary variable (such as household-specific unemployment shock) are evaluated at the means of other variables before being averaged.

A positive marginal effect of the shock reflects a higher likelihood of labor force participation for individuals who experienced the loss of another household member's job. Conversely, the negative marginal effect is indicative of the lower likelihood of labor force participation among individuals who experienced another household member's job loss. To the extent that the only difference between individuals identical in terms of observable characteristics is the loss of another household member's job, the higher (lower) likelihood can be interpreted as an indication that the person who, without the household member's job loss, 
would have been out of (in) the labor force had entered (exited) the labor force as a result of this shock. And it is in this sense that a positive result can be viewed as evidence of the added worker effect. This can be viewed as an indirect approach to assessing the added worker effect, with the direct one using a transition from inactive to active status as the dependent variable.

Other individual and household variables in the estimation include gender, age group, marital status, the level of educational attainment, and the number of children in the household. Macroeconomic characteristics account for country-level heterogeneity and include unemployment rate, per capita GDP in constant 2000 US\$, service share, industry share, government share, and export share, the last four all as percentages of GDP, based on the World Bank's World Development Indicators (WDI). Although their primary function in the estimation is to control for country-level heterogeneity, the inclusion of the unemployment rate and per capita GDP also allows us to evaluate the impact of macroeconomic environment on the probability of labor force participation separately from the impact of household-specific shocks. In order to make such inferences, we exploit the cross-country variation in the unemployment rate and per capita GDP (Aguiar, Hurst, and Karabarbounis 2011).

Due to the unavailability of the unemployment rate data for all the countries, we derive the unemployment rates from the dataset itself (the correlation coefficient between the surveybased unemployment rates and the available WDI-based unemployment rates is 75 percent). We use both unemployment rate and GDP per capita as indicators of macroeconomic environment because of a somewhat weak relationship between per capita GDP and unemployment rates in transition countries (EBRD 2012, 30). The use of service and industry shares is intended to capture the impact of sectoral differences on the labor force participation, as these differences can be important determinants of the variation in labor force participation rates. The government share serves as a proxy for the social safety net due to its potentially important role in explaining the presence of the need for secondary employment responses. Finally, the export share captures the variation in openness of the economies. In combining both household-level and macroeconomic data, this paper is similar in spirit to Cho and Newhouse (2012) and Bhalotra and Umaña-Aponte (2010). 


\section{DATA SUMMARY}

The unweighted sample consists of 60 percent women and 40 percent men, heavily skewed toward women. EBRD (2012) attributes the overrepresentation of females in the sample to the fact that the household members permanently away from home for work or studies, and hence excluded from the sample, are males. To correct for this feature of the data, EBRD introduced weights approximating the gender (and age) breakdown within each country's population. We use these weights in all of our estimations.

The labor force participation rates vary among men and women. The rate is 71.31 percent for women and 87.21 percent for men. The survey-based rates overestimate the labor force participation rates for 15-64 year olds from the WDI database, which are 60.01 percent for women and 73.71 percent for men. ${ }^{10}$ One reason for such overestimation might be the substantially lower labor force participation rates of 15-18 year olds dragging the WDI-based rate down because the WDI rates are based on 15-64-year-old individuals, whereas in our case the age range is 18-64 years old by survey design.

Survey responses reveal that a substantial portion of the households has been hurt by the crisis. In the final sample, 47.10 percent of the households report being affected a fair to a great deal by the crisis. The crisis was transmitted to them via several channels, the two most important ones being the drop in wages (26.49 percent of the total sample) and the employment loss of at least one household member (11.83 percent of the total sample) (Table 1).

Table 1 Household income shocks listed as the main way in which the crisis was experienced during the two years prior to the interview

\begin{tabular}{lr}
\hline Type of a shock & percentages \\
\hline Reduced wages $^{11}$ & 26.49 \\
At least one member lost a job & 11.83 \\
Reduced remittances & 8.27
\end{tabular}

\footnotetext{
${ }^{10}$ The WDI-based averages are based on 26 of the 29 transition countries, for which the data are available. The averages exclude Kosovo, Montenegro, and Serbia. Re-estimating the survey-based labor force participation rate for these 26 countries results in labor force participation rates of 72.65 percent for women and 87.77 percent for men, even higher than for the full sample.

${ }^{11}$ Household labor supply response may vary depending on the nature of the household-specific income shock. Given their pervasive nature, the responses that reduced wages initiate may have important implications for the analysis of labor force participation rates. Unfortunately, due to data limitations, we are unable to pursue this question. The reason is that we do not know the identity of the household members whose wages are reduced. As a result, we cannot argue that the labor force participation status of respondents is a response to another household member's wage reduction. In this context, the finding of a positive relationship between the wage reduction and the likelihood of labor force participation may be simply an outcome of the respondents experiencing wage reduction being employed to begin with.
} 
Delayed wages

Reduced working hours

A person who did not have a job found one

or someone who had a job took another one ${ }^{12}$

Increased working hours

Family business lost

Family member returned from abroad

Not applicable (not affected at all)

Note: weighted proportions
7.61

4.42

3.78

3.17

2.24

1.70

30.47

As can be seen from Table 2, about 15 percent of respondents experienced a household member's loss of a job (note that 11.83 percent reported that to be the main shock they experienced). About 67 percent of the respondents are married. The proportion of female respondents reporting having one or more children is higher for women than for men. This finding likely reflects a higher incidence of single motherhood compared to single fatherhood. Women are proportionately more educated compared to men, with 24.2 percent of females having tertiary education and only 21.66 percent of males, consistent with other evidence from the region (WB 2012).

Table 2 Summary statistics

\begin{tabular}{lcr}
\hline & Female & Male \\
\hline Labor force & 0.7131 & 0.8721 \\
Job loss other & 0.1447 & 0.1357 \\
Marriage & 0.6727 & 0.6621 \\
No children & 0.4917 & 0.5632 \\
1 child & 0.2432 & 0.2181 \\
2 or more children & 0.2650 & 0.2187 \\
Age 18-24 & 0.1144 & 0.1357 \\
Age 25-34 & 0.2942 & 0.3117 \\
Age 35-44 & 0.2594 & 0.2458 \\
Age 45-54 & 0.2373 & 0.2088 \\
Age 55-64 & 0.0947 & 0.098 \\
Secondary & 0.3475 & 0.3674 \\
Vocational & 0.1837 & 0.1665 \\
Tertiary & 0.2420 & 0.2166 \\
\hline
\end{tabular}

Note: weighted proportions

\footnotetext{
12 The response to this question could allow us to directly evaluate the added worker effect in employment (although not in labor force). However, similar to the wage reduction question, we are unable to identify the household member making the transition.
} 
Women's labor force participation rates are especially sensitive to individual and household characteristics (Table 3). For example, whereas labor force participation rates of married and unmarried men are similar, married women have a lower labor force participation rate than unmarried women. Similarly, men's labor force participation rates hardly vary in response to the number of children; however, for women, the rate drops, especially if there are two or more children in the household. Men have a wide peak age range, whereas women reach their peak labor force participation rates only after passing the child-bearing years. In sum, women's labor force participation appears to be much more strongly affected by their household responsibilities. With respect to educational attainment, labor force participation rates of men increase from 86.88 percent for complete secondary to 93.44 percent for tertiary education; however, the sensitivity is once again much higher among women. Female labor force participation rate increases from 67.54 percent for women with secondary education to 85.23 percent, a 17.69 percentage point variation, compared to 6.56 percentage points for men. This appears to suggest that women's labor force returns to education are higher than men's.

Table 3 Labor force participation rates, by gender, demographic group, and the job loss of another household member

\begin{tabular}{lrrrr}
\hline & \multicolumn{2}{c}{ Women } & \multicolumn{2}{c}{ Men } \\
& $\begin{array}{r}\text { No Job } \\
\text { loss }\end{array}$ & $\begin{array}{r}\text { Job } \\
\text { loss }\end{array}$ & No Job loss & Job loss \\
\hline Total & 0.7156 & 0.6985 & 0.8781 & 0.8339 \\
Unmarried & 0.8215 & 0.7743 & 0.8723 & 0.8012 \\
Married & 0.6614 & 0.6716 & 0.8811 & 0.8474 \\
Children 0 & 0.776 & 0.7711 & 0.8813 & 0.8418 \\
1 & 0.7216 & 0.7126 & 0.8872 & 0.8174 \\
$\quad 1$ & 0.5949 & 0.5713 & 0.8602 & 0.8327 \\
Age 18-24 & 0.6192 & 0.6094 & 0.8389 & 0.7507 \\
Age 25-34 & 0.6734 & 0.6498 & 0.8964 & 0.8466 \\
Age 35-44 & 0.7616 & 0.7064 & 0.8958 & 0.8621 \\
Age 45-54 & 0.7651 & 0.7800 & 0.8824 & 0.8741 \\
Age 55-64 & 0.7193 & 0.6720 & 0.8181 & 0.7623 \\
Secondary & 0.6717 & 0.6976 & 0.8774 & 0.8190 \\
Vocational & 0.7771 & 0.7654 & 0.9003 & 0.8819 \\
Tertiary & 0.852 & 0.8551 & 0.9393 & 0.8817 \\
\hline
\end{tabular}

Note: weighted proportions

Pertinent to our analysis, the labor force participation rate of women who experienced another household member's job loss is lower compared to the corresponding rate of women 
who did not. This seems to refute the hypothesis of the added worker effect. However, this pattern is reversed for married women, those who were 45-54 years old and women with secondary education. For men, across all categories, there is an unequivocal decrease in the labor force participation rate as a result of the loss of another household member's job. Next, we test these preliminary predictions in a multivariate framework.

\section{RESULTS}

\section{Loss of Another Household Member's Job}

\section{Women}

After controlling for individual, household and country-level characteristics, we find the presence of a mild added worker effect among women. Having experienced the loss of another household member's job raises the probability of women's labor force participation by 2.9 percentage points. The result is largely driven by married women, for whom the loss of another household member's job results in a 3.58 percentage point higher probability of labor force participation (Table 4). Furthermore, if we evaluate the added worker effect of married women with respect to the husband's loss of a job, the magnitude is substantially higher at 10.51 percentage points, at par with the estimates from other countries (e.g., Fernandes and de Felicio 2002; McKenzie 2004).

Age appears to play an important role in determining the likelihood of labor force participation as a result of a household income shock. The added worker effect is present among the 25-34-year-old women, with their probability of labor force participation increasing by 3.63 percentage points (although only at 10-percent significance level). The second age group, in which we observe the evidence of the added worker effect, is the group of 45-54-year-old women. For them, the probability of labor force participation in response to another household member's job rises by 4.32 percentage points. These women have passed their prime childbearing age and are likely to have older children. Consequently, the lower level of childcare responsibilities reduces their opportunity cost of work, hence raising their odds of entering the labor force in response to a household income shock.

The conjecture that child rearing serves as a formidable barrier for female labor force participation is further supported by the finding that the added worker effect is statistically significant only among women in the households without children. It is only in their case that 
the probability of labor force participation is higher, by 3.7 percentage points. For women with one or more children in the household, there is no evidence of the added worker effect.

An equally important role for women is played by their level of education, as the added worker effect is dominant only among the women with secondary education, potentially due to their higher vulnerability. Their probability of labor force participation rises by 5.34 percentage points in the case of a job loss of a household member. Women with vocational or tertiary education do not exhibit the added worker effect, their education likely serving as a proxy for the greater security against household income shocks.

We further explore the role that greater vulnerabilities might play in amplifying the impact of household income shocks on women's labor force participation. In particular, we investigate the possibility that the added worker effect is stronger among the households that face financial constraints, forcing them to increase their labor supply as a coping strategy (Lundberg 1985). We use two variables as proxies for financial constraints: owning a secondary residence and having a credit card. Owning a secondary residence likely reflects greater financial security as does having a credit card, which, in the absence of the earnings information, serves as an indicator of moderate and stable household income.

We find that women from the households that own secondary residences (8.32 percent of the sample) do not exhibit the added worker effect. In contrast, the effect is present among the women in households without secondary residence as their probability of being in the labor force increases by 3.08 percentage points in response to the loss of a household member's job. Further emphasizing the influence of financial constraints, women from households in which someone owns a credit card (22.78 percent of the sample) do not exhibit the added worker effect. On the other hand, among the women from the households in which no one owns a credit card, the probability of labor force participation increases by 3.52 percentage points in response to the loss of a household member's job. In sum, microeconomic vulnerabilities indeed amplify the impact of household income shocks.

In turn, in order to evaluate the extent to which macroeconomic conditions influence the presence of the added worker effect, we group the countries of the region into different categories, based on EU membership, unemployment rates, and per capita GDP. We find that the added worker effect among women is absent in the EU countries, but is present in the nonEU countries (4.37 percentage point increase), potentially due to the presence of stronger social insurance systems in the EU transition countries. This result is present even though government 
share in the GDP is included in the estimation, implying that it only partially accounts for the differences in social infrastructure. To a strong extent, the presence of the added worker effect appears to depend on economic factors. We find that in countries with the unemployment rate above 13 percent (mean unemployment rate in the region), the magnitude of the added worker effect is 3.22 percentage points, whereas the evidence in the countries with the below average unemployment rates is inconclusive. Further nuances emerge by grouping countries according to their per capita GDP. We find that it is the countries in the middle of the distribution $(\$ 2,000-$ $\$ 3,300)$ that drive the results, with the dominant added worker effect of 5.57 percentage points. The absence of the added worker effect in the countries with per capita GDP above \$3,300 (regional average in 2010) could potentially be attributed to the presence of stronger social insurance mechanisms. Indeed, Vodopivec, Woergoetter, and Raju (2005) argue that in these transition countries, unemployment benefits protected many households from falling into poverty. On the other hand, the absence of the added worker effect at the bottom of the regional distribution could be attributed to the weaker prospects of finding a job. Hence, on a macroeconomic scale, although a weaker institutional and macroeconomic environment may contribute to a stronger female added worker effect by depressing the prospects of finding a job, greater vulnerabilities can also negatively affect the decision to join the labor markets. Our findings appear to reveal an inverted-U relationship between the added worker effect and the level of economic development, measured by per capita GDP.

Table 4 Marginal effects of the job loss of another household member, by gender and subsamples (except for the second row results, which are the marginal effects of the spousal job loss)

\begin{tabular}{lll}
\hline & Women & Men \\
\hline Overall & 0.0290 & -0.0229 \\
& $(0.0117)^{* *}$ & $(0.0118)^{*}$ \\
Overall (with spousal loss of a job) & 0.1051 & -0.0294 \\
& $(0.0310)^{* * *}$ & $(0.0174)^{*}$ \\
Married & 0.0358 & -0.0195 \\
& $(0.0149)^{* *}$ & $(0.0133)$ \\
Unmarried & 0.0035 & -0.0411 \\
Age 18-24 & $(0.0221)$ & $(0.0238)^{*}$ \\
& 0.0444 & -0.0510 \\
Age 25-34 & $(0.0390)$ & $(0.0421)$ \\
Age 35-44 & 0.0363 & -0.0325 \\
Age 45-54 & $(0.0207)^{*}$ & $(0.0241)$ \\
& -0.0015 & -0.0225 \\
& $(0.0227)$ & $(0.0204)$ \\
\hline
\end{tabular}




\begin{tabular}{|c|c|c|}
\hline Age 55-64 & $\begin{array}{l}0.0103 \\
(0.0297)\end{array}$ & $\begin{array}{l}-0.0605 \\
(0.0427)\end{array}$ \\
\hline Secondary & $\begin{array}{l}0.0534 \\
(0.0206)^{* * *}\end{array}$ & $\begin{array}{l}-0.0444 \\
(0.0225)^{* *}\end{array}$ \\
\hline Vocational & $\begin{array}{l}-0.0038 \\
(0.0240)\end{array}$ & $\begin{array}{l}-0.0019 \\
(0.0290)\end{array}$ \\
\hline Tertiary & $\begin{array}{l}0.0131 \\
(0.0221)\end{array}$ & $\begin{array}{l}-0.0496 \\
(0.0307)\end{array}$ \\
\hline No children & $\begin{array}{l}0.0370 \\
(0.0138) * * *\end{array}$ & $\begin{array}{l}-0.0219 \\
(0.0163)\end{array}$ \\
\hline 1 child & $\begin{array}{l}0.0217 \\
(0.0214)\end{array}$ & $\begin{array}{l}-0.0470 \\
(0.0256)^{*}\end{array}$ \\
\hline 2 children or more & $\begin{array}{l}0.0187 \\
(0.0276)\end{array}$ & $\begin{array}{l}-0.0104 \\
(0.0222)\end{array}$ \\
\hline Credit card & $\begin{array}{l}0.0153 \\
(0.0207)\end{array}$ & $\begin{array}{l}-0.0217 \\
(0.0241)\end{array}$ \\
\hline No credit card & $\begin{array}{l}0.0352 \\
(0.0138)^{* *}\end{array}$ & $\begin{array}{l}-0.0224 \\
(0.0153)\end{array}$ \\
\hline Secondary residence & $\begin{array}{l}0.0132 \\
(0.0420)\end{array}$ & $\begin{array}{l}-0.0580 \\
(0.0486)\end{array}$ \\
\hline No secondary residence & $\begin{array}{l}0.0308 \\
(0.0128)^{* *}\end{array}$ & $\begin{array}{l}-0.0205 \\
(0.0117)^{*}\end{array}$ \\
\hline GDP per capita less than $\$ 1000$ & $\begin{array}{l}-0.0122 \\
(0.0363)\end{array}$ & $\begin{array}{l}-0.0148 \\
(0.0351)\end{array}$ \\
\hline$\$ 1,000-\$ 2,000$ & $\begin{array}{l}0.0246 \\
(0.0220)\end{array}$ & $\begin{array}{l}-0.0193 \\
(0.0247)\end{array}$ \\
\hline$\$ 2,000-\$ 3,300$ & $\begin{array}{l}0.0557 \\
(0.0185) * * *\end{array}$ & $\begin{array}{l}-0.0544 \\
(0.0224)^{* *}\end{array}$ \\
\hline GDP per capita $\$ 3,300$ or higher & $\begin{array}{l}0.0165 \\
(0.0192)\end{array}$ & $\begin{array}{l}-0.0049 \\
(0.0193)\end{array}$ \\
\hline $\begin{array}{l}\text { Unemployment rate } 13 \text { percent or } \\
\text { higher }\end{array}$ & $\begin{array}{l}0.0322 \\
(0.0138) * *\end{array}$ & $\begin{array}{l}-0.0283 \\
(0.0138)^{* *}\end{array}$ \\
\hline Unemployment rate $<13$ percent & $\begin{array}{l}0.0011 \\
(0.0231)\end{array}$ & $\begin{array}{l}-0.0085 \\
(0.0198)\end{array}$ \\
\hline Non-EU countries & $\begin{array}{l}0.0437 \\
(0.0131) * * *\end{array}$ & $\begin{array}{l}-0.0234 \\
(0.0150)\end{array}$ \\
\hline EU countries & $\begin{array}{l}0.0039 \\
(0.0191)\end{array}$ & $\begin{array}{l}-0.0211 \\
(0.0195)\end{array}$ \\
\hline
\end{tabular}

Note: $* * *$ p-value $<0.01, * *$ p-value $<0.05, *$ p-value $<0.10 ;$ average

marginal effects reported; cluster-adjusted standard errors

\section{Men}

In contrast to women, there is no evidence of the added worker effect among men. In fact, the opposite is the case: the loss of another household member's job is associated with a 2.29 percentage point decrease in the probability of labor force participation. This negative effect is especially pronounced among unmarried men with secondary education with one child in the household.

What can potentially explain the finding of the negative relationship? It is unlikely that men's greater involvement in household responsibilities in order to substitute for market goods 
is the culprit. ${ }^{13}$ The possibility that respondents increase their leisure time at the expense of searching for a job when another household member loses a job might not be a plausible explanation, either. A more likely explanation lies in the spurious correlation in male household members' labor force status. The negative labor supply responses of men may be a manifestation of the first-round effects of the crisis that men experienced more painfully than women because their employment was concentrated in industries that were hit the most. That is, the negative marginal effects could reflect not so much the response to the unemployment shock, but the correlation in employment status among men, which applies only to men and not to women due to the nature of their industrial segregation.

Further support for this possibility is rendered by the role that financial constraints play in men's labor force participation in relation to unemployment shocks. To the extent that greater household vulnerabilities are also associated with more vulnerable forms of employment and hence a higher likelihood of multiple male household members losing a job, financial constraints will amplify the negative relationship between the labor force participation of respondents and the unemployment shock. Indeed, although the evidence based on the ownership of a credit card is somewhat inconclusive (marginal effect is negative but insignificant), the evidence based on the ownership of a secondary residence reveals the presence of a negative relationship between labor force participation and unemployment shocks among the men whose households do not own a secondary residence.

Similar to microeconomic vulnerabilities, a weaker macroeconomic environment results in a stronger negative relationship, as we observe among the countries with the unemployment rates above 13 percent. Furthermore, the negative association is present only in the countries that are in the middle of the per capita GDP distribution $(\$ 2,000-\$ 3,300)$. Its absence among the richest countries of the region might be attributed to men in more affluent countries choosing to remain in the labor force instead of withdrawing from it because of the presence of a stronger unemployment insurance system. The absence of the negative correlation among the poorest countries of the region could potentially be attributed to their greater dependence on agriculture, which serves as a default employment type in many households in these countries.

\footnotetext{
${ }^{13}$ The finding of the negative marginal effect among married couples has been attributed to the assortative mating hypothesis, according to which, spouses share characteristics that make both more likely to experience similar shocks (Spletzer 1997).
} 


\section{Macroeconomic Factors}

Unlike the gender-dependent responses to household-specific unemployment shocks, the association between labor force participation and unemployment rates is negative for both women and men, revealing the presence of the discouraged worker effect (Table 5).

Furthermore, the discouraged worker effect is almost twice as strong for women as it is for men. Indeed, a 1-percentage point increase in the unemployment rate lowers the probability of labor force participation by 0.22 percentage points and by 0.12 percentage points for women and men, respectively.

For women, the marginal effect with respect to per capita GDP reinforces the finding of the discouraged worker effect, as a 1-percent decrease in per capita GDP is associated with a 0.0662 -percentage point decrease in the probability of labor force participation. ${ }^{14}$ For men, this relationship is insignificant.

The differences in the relationship of labor force participation rates to unemployment rates and to per capita GDP underscore a very weak connection between unemployment rates and per capita GDP in the transition countries (EBRD 2012). They also seem to reveal that weaker labor markets exert a stronger depressing pressure on the labor force participation rates than the drop in the GDP. The link between per capita GDP and labor force participation rates appears to be much looser for men, in particular.

Our findings hence indicate that men's drop in the labor force participation rate was likely a result of the initial unemployment shock due to their industrial concentration, but it was further compounded by the discouraged worker effect. For women, on the other hand, the discouraged worker effect was dominated by the added worker effect, contributing to an increase in the female labor force participation rate.

Table 5 Complete logit results, by gender

\begin{tabular}{lll}
\hline & Women & Men \\
\hline Job loss incidence & 0.0290 & -0.0229 \\
& $(0.0117)^{* *}$ & $(0.0118)^{*}$ \\
Marriage & -0.1156 & 0.0195 \\
& $(0.0103)^{* * *}$ & $(0.0100)^{*}$
\end{tabular}

${ }^{14}$ Note that the marginal effect with respect to $\ln$ (per capita GDP) is the same as semielasticity defined as $\mathrm{dy} / \mathrm{d} \ln (\mathrm{x})=\mathrm{dy} /((1 / \mathrm{x}) \mathrm{dx})=(\mathrm{dy} / \mathrm{dx})^{*} \mathrm{x}$, where $\mathrm{x}=\ln ($ per capita GDP $)$. Hence, in this case, a doubling of per capita GDP is associated with a 6.62-percentage point increase in female labor force participation. 


\begin{tabular}{|c|c|c|}
\hline Age 18-24 & $\begin{array}{l}-0.1602 \\
(0.0195)^{* * *}\end{array}$ & $\begin{array}{l}-0.0382 \\
(0.0190)^{* *}\end{array}$ \\
\hline Age $25-34$ & $\begin{array}{l}-0.0997 \\
(0.0126)^{* * *}\end{array}$ & $\begin{array}{l}-0.0039 \\
(0.0125)\end{array}$ \\
\hline Age $45-54$ & $\begin{array}{l}-0.0292 \\
(0.0119) * *\end{array}$ & $\begin{array}{l}-0.0184 \\
(0.0135)\end{array}$ \\
\hline Age 55-64 & $\begin{array}{l}-0.122 \\
(0.0186) * * *\end{array}$ & $\begin{array}{l}-0.0946 \\
(0.0186)^{* * *}\end{array}$ \\
\hline Secondary & $\begin{array}{l}0.0876 \\
(0.0112)^{* * *}\end{array}$ & $\begin{array}{l}0.0452 \\
(0.0086)^{* * *}\end{array}$ \\
\hline Vocational & $\begin{array}{l}0.1488 \\
(0.0113)^{* * *}\end{array}$ & $\begin{array}{l}0.0604 \\
(0.0097)^{* * *}\end{array}$ \\
\hline Tertiary & $\begin{array}{l}0.2151 \\
(0.0107)^{* * *}\end{array}$ & $\begin{array}{l}0.0924 \\
(0.0092) * * *\end{array}$ \\
\hline \# of children & $\begin{array}{l}-0.0335 \\
(0.0051)^{* * *}\end{array}$ & $\begin{array}{l}-0.0062 \\
(0.0041)\end{array}$ \\
\hline $\begin{array}{l}\text { Unemployment } \\
\text { rate }\end{array}$ & $\begin{array}{l}-0.0022 \\
(0.0005)^{* * *}\end{array}$ & $\begin{array}{l}-0.0012 \\
(0.0005)^{* *}\end{array}$ \\
\hline $\begin{array}{l}\text { Log GDP per } \\
\text { capita }\end{array}$ & $\begin{array}{l}0.0662 \\
(0.0087)^{* * *}\end{array}$ & $\begin{array}{l}-0.0081 \\
(0.0088)\end{array}$ \\
\hline Service share & $\begin{array}{l}0.0007 \\
(0.0014)\end{array}$ & $\begin{array}{l}0.0013 \\
(0.0012)\end{array}$ \\
\hline Industry share & $\begin{array}{l}-0.0035 \\
(0.0014)^{* *}\end{array}$ & $\begin{array}{l}0.0007 \\
(0.0012)\end{array}$ \\
\hline Government share & $\begin{array}{l}-0.0025 \\
(0.0014)^{*}\end{array}$ & $\begin{array}{l}-0.0059 \\
(0.0015)^{* * *}\end{array}$ \\
\hline Exports & $\begin{array}{l}0.0011 \\
(0.0003)^{* * *}\end{array}$ & $\begin{array}{l}0.0015 \\
(0.0003) * * *\end{array}$ \\
\hline $\mathrm{N}$ & 18,243 & 18,243 \\
\hline
\end{tabular}

\section{Individual and Household Factors}

Our results also shed light on the impact of individual and household characteristics on the labor force participation rates of men and women. They reveal patterns similar to the ones exhibited in other parts of the world (Sabarwal, Sinha, and Buvinic 2011). Focusing on women's results, we observe that marriage lowers their probability of labor force participation by 11.56 percentage points (Table 5). The prime age window of women is rather narrow: 35-44-year-old women exhibit the highest labor force participation rates. The lowest rates are present among 
the youngest and the pre-retirements groups. This result also provides another explanation for why 45-54-year-old women are the primary drivers of the added worker effect, as their initial labor force participation rates are lower than the rates for 35-44-year-old women. Education increases the probability of labor force participation among women: completing secondary education raises the probability of labor force participation rate by 8.76 percentage points and these returns increase to 14.88 percentage points for vocational education and 21.51 percentage points for tertiary education. Hence, the finding that the added worker effect is the strongest among women with secondary education could be partly driven by their lower initial labor force participation rates. Each additional child in the household reduces the probability of labor force participation of women by 3.35 percentage points.

For men, the picture is somewhat different. Marriage plays a slightly positive role in explaining their labor force participation, whereas having children has no effect on it. Men's prime age window is much wider than women's and includes individuals between the ages of 25 and 55, i.e., three age groups. On the other hand, similar to women, the youngest and the preretirement groups have the lowest probabilities of labor force participation. Education increases the probability of labor force participation, but its effect for men is substantially smaller than it is for women. Completing secondary education increases the probability of men's labor force participation only by 4.52 percentage points. The increase in men's labor force participation rate is only 6.04 percentage points as a result of completing vocational education and 9.24

percentage points as a result of completing tertiary education. Hence, the returns to education in terms of labor force participation are indeed higher for women.

\section{Caveats and Robustness Checks}

In interpreting our results, several caveats need to be kept in mind. One such caveat is that the presence of a relationship between the job loss of another household member and labor force status in principle only implies correlation rather than causation. For example, if household members operate in similar industries, the job loss of another household member may be associated with - though not cause - a transition from employment to inactive status for the respondent. In such a case, we will observe a negative relationship and, we argue, it is this reason that explains the negative association between the male labor force participation rate and the household employment shock. 
Furthermore, the use of the labor force participation status rather than the transition between statuses necessitates caution when interpreting the presence of the marginal effect as a sign of the transition into and out of the labor force. For example, if individuals from minority ethnic groups have a higher job loss probability (e.g., due to industrial or occupational segregation) as well as a higher initial probability of labor force participation, the positive marginal effect may be purely driven by the ethnic factor rather than the employment shock. In such a case, the coefficient will be overestimated and, for the purposes of our interpretation, although some transition might still take place, at least a portion of the higher likelihood could be attributed to the ethnic differences.

Another issue might arise from the fact that the precise cause for the job loss is not known. It is possible, for example, that another household member's loss of a job is a reaction to the respondent's change in the labor force status, potentially biasing the results. This could happen if a husband exits the labor force voluntarily as a response to his wife entering the labor force. However, given the challenging economic environment during this period, it is reasonable to assume that for the vast majority of the households, the job loss was involuntary. Finally, we do not know whether the household member who lost the job has found a new one. If so, our coefficient will underestimate the magnitude of the dominance of the added worker effect, since some of the individuals who lost a job may have found it, no longer requiring that the respondents enter the labor market.

We assess the robustness of our findings by re-estimating the model using several different specifications. We estimate it by no longer excluding the data for the inactive individuals who were retired or students, with no significant change in the results. To assess the sensitivity of the results to the measures of macroeconomic environment, we conduct the estimation using the WDI-based unemployment rate data instead of the survey-based unemployment rates. The impact of the unemployment rate on the labor force participation rate using either measure was similar, confirming the validity of our results. However, the inclusion of the full sample countries increases the efficiency of our results, rendering support to the preferred specification that includes survey-based unemployment rate data.

In addition, in order to analyze whether the added worker effect is driven by the entry into agricultural labor force, we limit the observations to individuals not involved in agricultural activities. We do so by taking advantage of the survey question that asks whether sales or bartering of farm products constitutes a source of livelihood for the households. This re- 
estimation potentially reduces the possibility of a bias due to the ambiguous classification of unpaid workers since the employment is defined in terms of the work for pay. Our findings confirm the presence of an added worker effect among women and, once again, of a negative correlation among men.

Finally, due to the nature of the dataset, which includes individual and country-level variables, we account for the possibility that the error-terms within countries are correlated by clustering for countries (rather than survey-based PSUs). The added worker results remain significant. Our preferred specification is the one that clusters for the survey-based PSUs in order to allow for comparability when regional sub-samples are analyzed.

\section{CONCLUSIONS}

The recent crisis was associated with a spike in women's labor force participation rate and a dip in men's labor force participation rate. Different mechanisms may have played a role in contributing to or counteracting these shifts. In this paper, we investigated the extent to which these changes may have been due to the distress response to the crisis using the data from 28 transition countries.

We find the presence of the added worker effect among women, indicating that the added worker effect is indeed a likely factor explaining the increase in the labor force participation rate of women. The added worker effect among women is present in the context of both spousal relationships and in the context of a general household setup in contrast to other studies (e.g., Cunningham 2001), highlighting the importance of a more extended household structure than seen in advanced and many developing economies. The added worker effect among women is driven by married 45-54-year-old women with secondary educations who have no children in the household. The presence of children in the home remains a formidable barrier to joining the labor force even when households experience income shocks. Individual and household-level vulnerabilities strengthen the female added worker effect, in line with the findings from other countries (Sabarwal, Sinha, and Buvinic 2011). We find that variations in both institutional and economic characteristics play a role in determining the presence of the female added worker effect. Indeed, the evidence of the added worker effect is found only in the non-EU countries. Furthermore, the added worker effect is stronger in weaker labor market environments, modeled in terms of above-average unemployment rates. On the other hand, in 
terms of per capita GDP, the added worker effect is present only among the countries in the middle of the per capita GDP distribution. We conjecture that the appearance of the inverted-U relationship can be explained by the presence of a well-developed social insurance system among the more affluent countries of the region and by the low odds of finding a job in the poorer countries of the region.

In the case of men, there is evidence of a negative correlation between the loss of another household member's job and labor force participation rate, driven by unmarried men with secondary educations and one child in the household. The negative correlation is present among men who are financially more vulnerable. Furthermore, the correlation is stronger in the countries with higher unemployment rates and per capita GDP in the middle of the distribution. We contend that the negative relationship is less likely to indicate their withdrawal from the labor force as a response to the loss of another household member's job. A more likely explanation is that it is a result of a greater correlation in the labor force status of men because they tend to concentrate in the industries that experienced greatest job losses during this crisis.

Unlike the responses to household-specific income shocks that differ between the two genders, weak macroeconomic conditions appear to depress the labor force participation outcomes of both men and women. In particular, higher unemployment rates result in lower labor force participation rates among both men and women, hinting at the presence of the discouraged worker effect on a macroeconomic scale that cuts across genders. For women, this effect is also present with respect to per capita GDP, as their labor force participation rate increases in per capita GDP.

Addressing the original goal of this paper, our findings reveal that the decrease in men's labor force participation during this crisis is likely a combined result of the first-round sectoral contraction and the second-order discouraged worker effect as a response to the weaker labor market environment. For women, on the other hand, the added worker effect appears to have outweighed the discouraged worker effect, contributing to an increase in their labor force participation rate.

These findings underscore that the responses to household-specific microeconomic shocks cannot be divorced from the macroeconomic context in which individual and household decisions are made. The need for individuals' labor supply responses and the magnitude of these responses depend on macroeconomic conditions. 
Future work needs to explore the long-term consequences of the added worker effect especially due to its distress connotation, as some studies have found that the work experience gained by female added workers improved their competitiveness in the labor market (Posadas and Sinha 2010). More work is needed to understand the role that variations in institutional characteristics, such as unemployment insurance schemes and financial systems, may play in determining the strength of the added worker effect in transition countries. Beyond the added worker effect, it will be important to assess the extent to which the added workers in transition countries have been able to realize their desire to work and evaluate the quality of the created employment opportunities. 


\section{REFERENCES}

Aguiar, M., E. Hurst, and L. Karabarbounis. 2011. "Time Use during Recessions.” NBER Working Paper 17259. Cambridge, MA: National Bureau of Economic Research.

Antonopoulos, R. 2009. "The Current Economic and Financial Crisis: The Gender Perspective." Working Paper No. 562. Annandale-on-Hudson, NY: Levy Economics Institute of Bard College.

Başlevent, C. and Ö. Onaran. 2003. “Are Married Women in Turkey More Likely to Become Added or Discouraged Workers?" Labour 17: 439-58.

Bhalotra, S. and M. Umaña-Aponte. 2010. “The Dynamics of Women's Labour Supply in Developing Countries.” IZA Discussion Paper 4879. Bonn, Germany: IZA.

Cerrutti, M. 2000. "Economic Reform, Structural Adjustment and Female Labour Force Participation in Buenos Aires, Argentina." World Development 28: 879-91.

Cho, Y. and D. Newhouse. 2013. "How Did the Great Recession Affect Different Types of Workers? Evidence from 17 Middle-Income Countries." World Development 41: 31-50.

Congregado, E., A.A. Golpe, and A. van Stel. 2011. "Exploring the Big Jump in the Spanish Unemployment Rate: Evidence on an 'Added Worker Effect."' Economic Modelling 28: 1099-1105.

Cunningham, W. 2001. "Breadwinner or Caregiver? How Household Role Affects Labour Choices in Mexico.” World Bank Policy Research Working Paper No. 2743. Washington, DC: World Bank.

European Bank for Reconstruction and Development. 2009. Transition in Crisis? Annual Report. London, UK: European Bank for Reconstruction and Development.

- 2012. Life in Transition: After the Crisis. London, UK: European Bank for Reconstruction and Development.

- 2013. "Regional Economic Perspectives in EBRD Countries of Operations: January 2013." EBRD Office of the Chief Economist. London, UK: European Bank for Reconstruction and Development.

Fernandez, R. and F. De Felicio. 2005. "The Entry of the Wife into the Labour Force in Response to the Husband's Unemployment: A Study of the Added Worker Effect in Brazilian metropolitan areas." Economic Development and Cultural Change 53: 887911.

Gong, X. 2011. "The Added Worker Effect for Married Women in Australia." The Economic Record 87: 414-26.

Greene, W.H. 2003. Econometric Analysis, 5th edition. Upper Saddle River, NJ: Prentice Hall. 
Heltberg, R., N. Hossain, A. Reva, and C. Turk. 2012. "Anatomy of Coping: Evidence from People Living through the Crises of 2008-11." World Bank Policy Research Working Paper 5957. Washington, DC: World Bank.

İlkkaracan, I. and S. Değirmenci. 2013, forthcoming. "Economic Crises and the Added Worker Effect in the Turkish Labour Market." In R. Antonopoulos (ed.), Gender Perspectives on the Global Economic Crisis. London, UK: Routledge.

International Labour Organization. 2010. Women in Labour Markets: Measuring Progress and Identifying Challenges. Geneva, Switzerland: International Labour Office.

—. 2012. Global Employment Trends for Youth 2012. Geneva, Switzerland: International Labour Office.

Juhn, Ch. and S. Potter. 2007. "Is There Still an Added Worker Effect?" FRBNY Staff Report No. 310. New York, NY: Federal Reserve Bank of New York.

Karaoglan D. and C. Okten. 2012. "Labour Force Participation of Married Women in Turkey: Is There an Added or a Discouraged Worker Effect?” IZA Discussion Paper 6616. Bonn, Germany: IZA.

Lokshin, M. and R. Yemtsov. 2004. "Household Strategies for Coping with Poverty and Social Exclusion in Post-Crisis Russia." Review of Development Economics 8: 15-32.

Lundberg, S. 1985. “The Added Worker Effect.” Journal of Labour Economics 3: 11-37.

McKenzie, D. 2003. "How Do Households Cope with Aggregate Shocks? Evidence from the Mexican Peso Crisis." World Development 31: 1179-99.

- 2004. "Aggregate Shocks and Urban Labour Market Responses: Evidence from Argentina's financial Crisis.” Economic Development and Cultural Change 52: 719-58.

McLaren, Z.M. 2012. “Coping with Intrahousehold Job Separation in South Africa's Labour Market.” IZA Working Paper 6811. Bonn, Germany: IZA.

Posadas, J. and N. Sinha. 2010. "Persistence of the Added Worker Effect: Evidence Using Panel Data from Indonesia?" Mimeo. Washington, DC: World Bank.

Prieto-Rodriguez, J. and C. Rodriguez-Gutierrez. 2003. "Participation of Married Women in the European Labour Markets and the 'Added Worker Effect."' Journal of Socio-Economics 32: 429-46.

Rubery, J. (ed.). 1988. Women and Recession. London, UK: Routledge.

Sabarwal S., N. Sinha, and M. Buvinic. 2011. "How Do Women Weather Economic Shocks? A Review of the Evidence.” World Bank Research Working Paper 5496. Washington, DC: World Bank. 
Serneels, P. 2002. "The Added Worker Effect and Intrahousehold Aspects of Unemployment." Centre for the Study of African Economies Working Paper 2002-14. Oxford, UK: Centre for the Study of African Economies.

Singh A. and A. Zammit. 2000. "International Capital Flows: Identifying the Gender Dimension." World Development 28: 1249-68.

Skoufias, E. and S.W. Parker. 2004. "The Added Worker Effect over the Business Cycle: Evidence from Urban Mexico." Applied Economics Letters 11: 625-30.

Spletzer J.R. 1997. "Reexamining the Added Worker Effect." Economic Inquiry 35: 417-27.

Stephens, M., Jr. 2002. "Worker Displacement and the Added Worker Effect." Journal of Labour Economics 20: 504-37.

Unal, F.G., M. Dokmanovic, and R. Abazov. 2010. "The Economic and Financial Crises in CEE and CIS: Gender Perspectives and Policy Choices." Working Paper No. 598. Annandaleon-Hudson, NY: Levy Economics Institute of Bard College.

United Nations. 2013. World Economic Situation and Prospects 2013: Global Outlook. New York, NY: United Nations.

-2009. Gender Gap and Economic Policy: Trends and Good Practices from the ECE Region. Geneva, Switzerland: United Nations.

United States Census Bureau. 2012. "Census Bureau Reports More Adults Living in Shared Households, More Receiving Food Stamps, Public Assistance Unchanged." Press release, November 28.

http://www.census.gov/newsroom/releases/archives/american_community_survey_acs/c b12-224.html

Vodopivec, M., A. Woergoetter, and D. Raju. 2005. "Unemployment Benefit Systems in Central and Eastern Europe: A Review of the 1990s." Comparative Economic Studies 47: 615-51.

World Bank. 2012. Opportunities for Men and Women: Emerging Europe and Central Asia. Washington DC: World Bank. 